\title{
МОРФОЛОГІЧНІ ЗМІНИ СЕРЦЯ У ТВАРИН З ЕКСПЕРИМЕНТАЛЬНИМ СИСТЕМНИМ ЧЕРВОНИМ ВОВЧАКОМ
}

\author{
๑О. В. Синяченко ${ }^{1}$, А. В. Бреславець ${ }^{2}$, Є. Д. Єгудіна ${ }^{3}$ \\ Донецький національний медичний університет ${ }^{7}$, м. Лиман \\ Науково-практичний центр клінічної та профілактичної медицини², м. Київ \\ Дніпропетровська державна медична академія ${ }^{3}$, м. Дніпро
}

РЕЗЮМЕ. Патологія серця при системному червоному вовчаку (СЧВ) належить до найчастіших проявів захворювання і багато в чому визначає його прогноз, а морфологічні зміни уражень міокарда, ендокарда та коронарних судин залишаються вивченими недостатньо. Гістологічна оцінка окремих кардіальних структур проводиться на природних моделях СЧВ у лінійних мишей.

Мета - вивчити в експерименті на тваринах (щурах) з моделлю СЧВ ступінь ушкодження міокарда, ендокарда й судин серця, зіставивши отримані результати з даними гістологічного дослідження тканин тимуса та селезінки.

Матеріал і методи. Моделювання СЧВ виконано на 53 білих безпородних щурах (34 самиці і 19 самців) з використанням уведень повного адъюванта Фрейнда, селезінкової дезоксирибонуклеїнової кислоти великої рогатої худоби, циклофосфаміду, азиду й дезоксирибонуклеїнату натрію, вигодовуванням тварин з додаванням в їжу сульфату кадмію, оксибутирату літію і молібдату амонію. Гістологічні препарати серця забарвлювали гематоксиліном та еозином, альціановим синім ( $\mathrm{pH}=2,6)$, за ван Гізон, ставилась PAS-реакція.

Результати. Експериментальний СЧВ супроводжується розвитком кардіопатії в усіх тварин з гіпертрофією, дистрофією і некрозом кардіоміоцитів, морфологічними ознаками склерозу коронарних судин, строми міокарда, ендокарда та клапанів серця, проліферацією судинного ендотелію, яка має дисперсійні й прямі кореляційні зв'язки зі ступенем лімфомакрофагальної інфільтрації інтерстицію, периваскулярною і клапанною гістіоцитарною клітинною інфільтрацією, а характер ушкоджень ендотелію судин щільно пов'язаний з наявністю в стромі міокарда хмарних клітин, визначається некрозом ендокарда та колагенолізом клапанів, зменшенням лімфоїдної тканини в селезінці, а також клітин в мозковому шарі і тілець Гассаля в тимусі.

Висновки. При експериментальній вовчаковій кардіопатії спостерігається закономірне ураження усіх структур серця, причому в їх патогенетичних побудовах беруть участь імунні порушення, на що вказують ушкодження відповідних структур імунокомпетентних органів - тимуса і селезінки.

КлючовІ СлОвА: системний червоний вовчак; модель; щури; серце; морфологія.

Вступ. Патологія серця при системному червоному вовчаку (СЧВ) належить до найчастіших проявів захворювання і багато в чому визначає його прогноз [1-3]. У переважній більшості випадків СЧВ виявляють зміни систоло-діастолічної функції лівого шлуночка $[4,5]$, а у деяких пацієнтів також дисфункції правого шлуночка і передсердя $[6,7]$. Добре відомі спостереження раптової смерті хворих на СЧВ внаслідок гострої серцевої недостатності [8].

Ознаки ураження серця при СЧВ у вигляді міокардиту, коронариту, інфаркту міокарда, порушень кардіального ритму (процесів збудливості й електричної провідності) вельми неспецифічні, часто-густо складні для діагностики, а різні ланки їх патогенезу вимагають уточнення [9-11]. Осо6ливої значущості набуває вовчаковий ендокардит Лібмана-Сакса $[12,13]$ з формуванням клапанних вад серця [14]. Нині в експерименті ураження серця при СЧВ вивчають на мишах ліній NZM (NZB/W, NZB/BXSB), JunB- $\triangle \mathrm{ep}, \mathrm{MRL}$ (MRL/lpr, $\mathrm{MRL} / \mathrm{MpJ}$ ), BALB/c, C3H/HеJ та ін., які $\epsilon$ природними моделями захворювання.

Мета - вивчити в експерименті на тваринах (щурах) із запропонованою штучною моделлю
СЧВ ступінь ушкодження міокарда, ендокарда й судин серця, зіставивши отримані результати 3 даними гістологічного дослідження тканин тимуса та селезінки.

Матеріал і методи дослідження. Моделювання СЧВ виконано на 60 білих безпородних щурах із середньою масою 220 г; до закінчення експерименту залишилися живими 53 особини (34 самиці та 19 самців), які й увійшли до об'єкту дослідження. 20 інтактних щурів (12 самиць і 8 самців) склали контрольну групу. Методика створення моделі СЧВ полягала в наступному. Під ефірним інгаляційним наркозом в корінь хвоста уводили повний адъювант Фрейнда (ПАФ) і розчин селезінкової дезоксирибонуклеїнової кислоти (ДНК) великої рогатої худоби (по 5 мг/кг маси тварини), а також впродовж трьох днів внутрішньочеревно вводили азид натрію (по 2 мг/кг). За два тижні від початку експерименту внутрішньом'язово додатково уводили циклофосфамід (100 мг/кг), а в корінь хвоста - ПАФ і ДНК (по 2,5 мг/кг). 3 наступної доби упродовж одного тижня тварини щодня отримували внутрішньом'язові ін 'єкції дезоксирибонуклеїнату натрію (20 мг/кг), після чого повторювали введення циклофосфаміду (100 мг/кг), 
Огляди літератури, оригінальні дослідження, погляд на проблему

ПАФ (1,5 мг/кг) та ДНК (1,5 мг/кг). Потім ще впродовж 7 днів щодня уводили дезоксирибонуклеїнат натрію (20 мг/кг). Через два місяці від початку дослідження на тлі внутрішньочеревного нембуталового наркозу (50 мг/кг) тварин виводили з експерименту. Дослідження схвалено комісією з біоетики Донецького національного медичного університету відповідно до рішення I Національного комітету з біоетики (Київ, 2000) та з положеннями Європейської конвенції із захисту хребетних тварин при їх використанні задля експериментальних біомедичних наукових цілей.

Гістологічні препарати тканин серця, тимуса і селезінки забарвлювали гематоксиліном і еозином, за ван Гізон, альціановим синім $(\mathrm{pH}=2,6)$, ставили PAS-реакцію. Середній показник пошкоджень (СПП) окремих структур вивчали за форму-

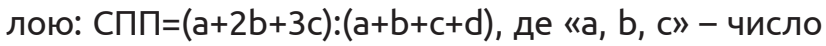
тварин відповідно з 1, 2 та 3 балами, a $\mathrm{d}-$ число тварин з відсутністю даної ознаки. Статистичну обробку отриманих результатів досліджень проведено за допомогою комп'ютерного варіаційного, непараметричного, кореляційного, одно- (ANOVA) й багатофакторного (ANOVA/MANOVA) дисперсійного аналізу (програми «Microsoft Excel» та «StatisticaStat-Soft», США). Оцінювали середні значения (M), їх стандартні похибки (SE) та відхилення (SD), параметричні коефіцієнти кореляції Пірсона (г) і непараметричні Кендалла ( $\tau)$, критерії дисперсії Брауна-Форсайта (BF) й Уїлкоксона-Рао (WR), відмінності Стьюдента (t) та вірогідність статистичних показників (р). Критичний рівень значущості при перевірці статистичних гіпотез у даному дослідженні приймали за такий, що дорівнював 0,05.

Результати й обговорення. Частота окремих морфологічних ознак (в порядку спадання) експериментальної вовчакової кардіопатії у тварин з

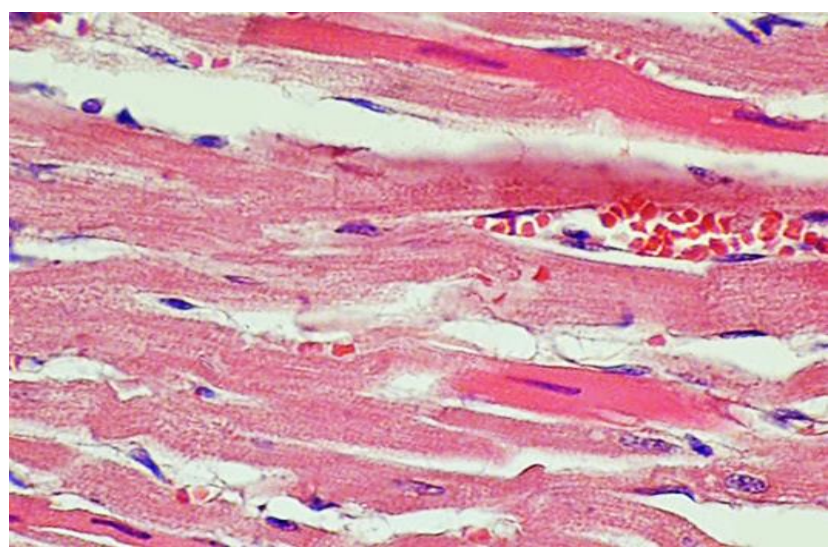

Рис. 1. Міокард щура з моделлю СЧВ. Венозне повнокров я, зерниста та вакуольна дистрофія кардіоміоцитів, периваскулярний склероз, лімфогістіоцитарна інфільтрація, проліферація ендотелію дрібних судин. Забарвлення гематоксилином та еозином, 36. ×400. моделлю СЧВ виявилася наступною: у 92,5 \% випадків виявлено периваскулярний склероз, в $86,8 \%$ - склероз строми міокарда, в 79,3 \% - некроз кардіоміоцитів, в 75,5\% - набряк строми, в 69,8 \% - ії лімфоцитарно-макрофагальну інфільтрацію, в 67,9 \% - спазм коронарних судин, в $62,3 \%$ - склероз клапанів, в 58,5\% - проліферацію судинного ендотелію, по 54,7 \% - відповідно гіпертрофію та дистрофію кардіоміоцитів, відповідно в 43,4 \% - склероз/гіаліноз судин і склероз ендокарда, в 39,6 \% - венозне повнокров'я, в 35,9 \% - відповідно периваскулярну інфільтрацію й клітинну інфільтрацію клапанів, в 32,1 \% - інфільтрацію строми хмарними клітинами (тканинними базофілами), в 26,4 \% - колагеноліз клапанів, в 18,9 \% - клітинну інфільтрацію ендокарда, в $13,2 \%$ - проліферацію клапанного ендотелію, в $9,4 \%$ - некроз ендокарда. СПП усіх структур серця $(\mathrm{M} \pm \mathrm{SD} \pm \mathrm{SE})$ склав $1,38 \pm 0,572 \pm 0,079$ у.о., кардіоміо-

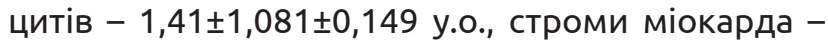
$1,39 \pm 0,570 \pm 0,078$ у.о., судин $-1,36 \pm 0,670 \pm 0,092$ у.о. Приклади варіантів морфологічних змін окремих структур серця при вовчаковій експериментальній кардіопатії за даними гістологічних препаратів подано на рисунках 1-4.

Ступінь периваскулярного фіброзу склав $(2,28 \pm 0,149)$ балів, некрозу кардіоміоцитів $(1,85 \pm 0,180)$ балів, лімфомакрофагальної інфільтрації строми - $(1,77 \pm 0,197)$ балів, проліферації ендотелію судин - $(1,36 \pm 0,181)$ балів (решта показників знайшла своє відображення на рисунку 5).

Ми відібрали ті ознаки експериментальної вовчакової кардіопатії, які одночасно мали дисперсійні зв'язки Брауна-Форсайта та непараметричні кореляційні Кендалла. Виявилось, що на гіпертрофію кардіоміоцитів прямо впливають виразність периваскулярної клітинної інфільтрації $(\mathrm{BF}=4,84$,

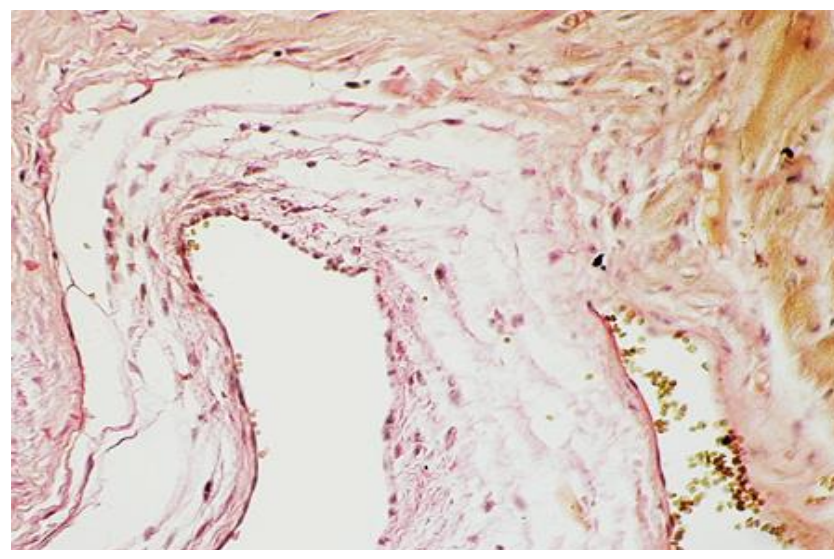

Рис. 2. Серце щура з моделлю СЧВ. Субендокардіальний і периваскулярний склероз, склероз в клапані, середній оболонці судин та в міжм'язовому просторі. Забарвлення за ван Гізон, зб. ×200 
Огляди літератури, оригінальні дослідження, погляд на проблему

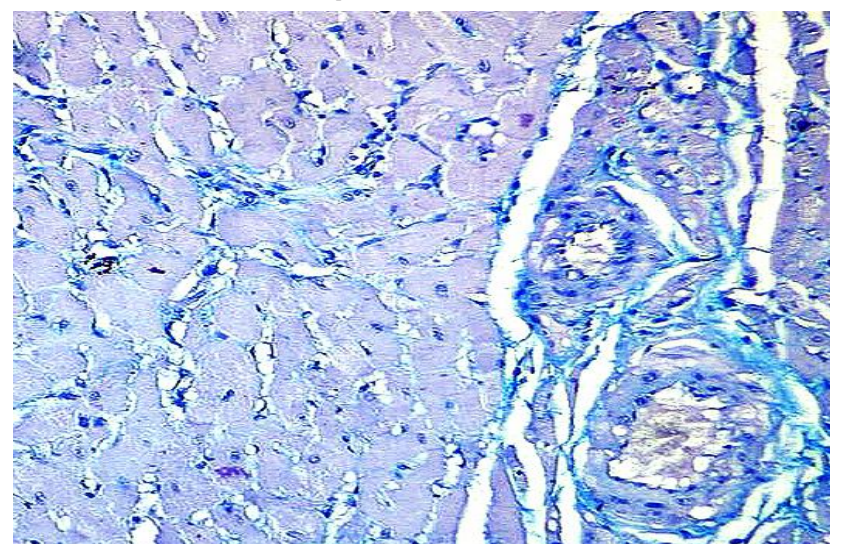

Рис. 3. Серце щура з моделлю СЧВ. Альціанофільні вогнища сполучної тканини між кардіоміоцитами, навколо судин і в сосочкових м'язах. Забарвлення альціановим синім (pH=2.6), 36. ×200

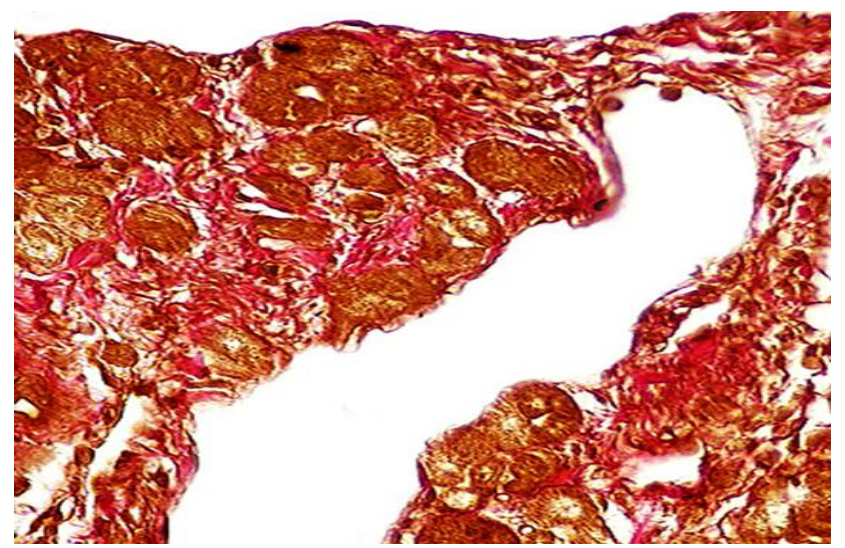

Рис. 4. Міокард щура з моделлю СЧВ. Підендокардіальний периваскулярний склероз сосочкових м'язів. Забарвлення за ван Гізон, зб. ×400

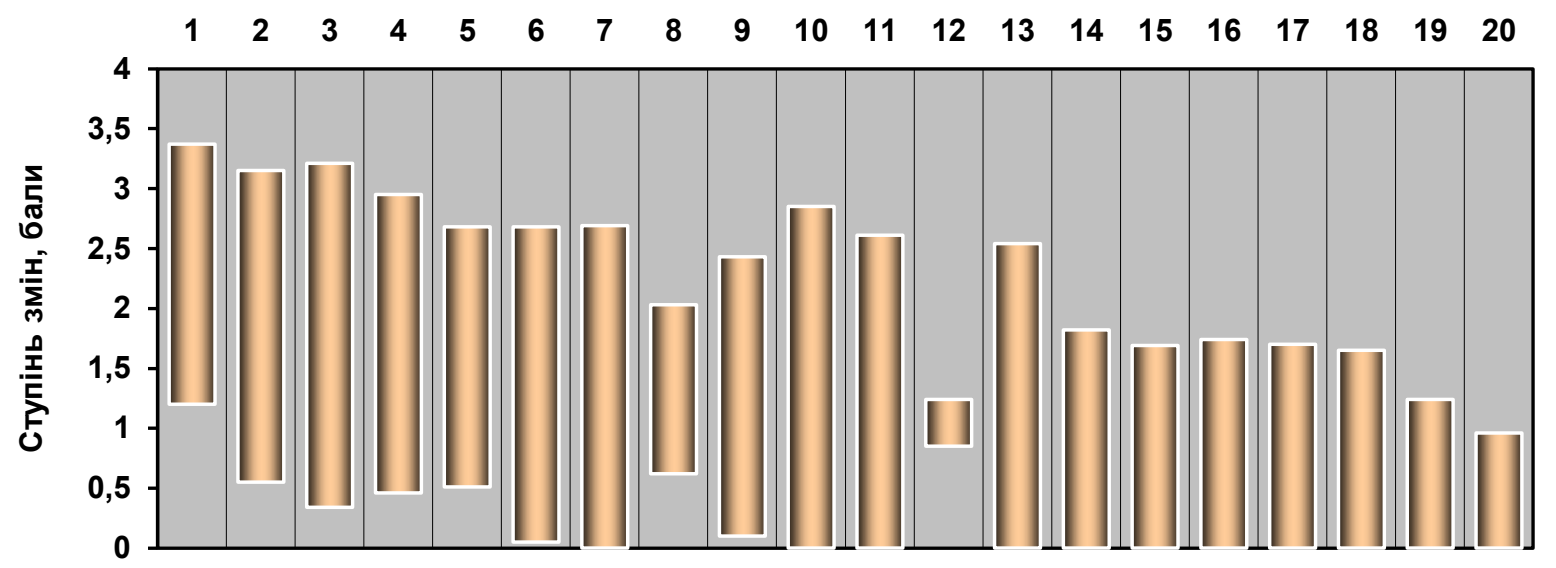

Рис. 5. Виразність окремих морфологічних ознак експериментальної вовчакової кардіопатії у щурів (<M $\pm \mathrm{SD}>$ бали).

1 - периваскулярний фіброз; 2 - некроз кардіоміоцитів; 3 - лімфомакрофагальна інфільтрація строми; 4 спазм коронарних судин; 5 - набряк строми міокарда; 6 - проліферація ендотелію судин; 7 - гіпертрофія кардіоміоцитів; 8 - склероз строми міокарда; 9 - склероз клапанів; 10 - склероз ендокарда; 11 - венозне повнокров'я серця; 12 - дистрофія кардіоміоцитів; 13 - периваскулярна інфільтрація; 14 - склероз/гіаліноз судин; 15 - клітинна інфільтрація клапанів; 16 -інфільтрація строми тканинними макрофагами; 17 - колагеноліз клапанів; 18 - клітинна інфільтрація ендокарда; 19 - проліферація клапанного ендотелію; 20 - некроз ендокарда.

$\mathrm{p}=0,002 ; \tau=+0,465, \mathrm{p}<0,001)$, проліферації ендотелію судин і клапанів (відповідно $B F=5,38, p=0,001$; $\tau=+0,236, p=0,013$ i $B F=18,2, p<0,001 ; \tau=+0,471$, $\mathrm{p}<0,001)$, а на некротизацію кардіоміоцитів - ступінь периваскулярного склерозу ( $\mathrm{BF}=2,47$, $p=0,046 ; \tau=+0,201, p=0,034)$. Як показав багатофакторний аналіз Уїлкоксона-Рао, зміни судинного ендотелію впливають на інтегральні прояви ушкоджень строми міокарда (WR=7,25, $\mathrm{p}<0,001)$, ендокарда ( $W R=2,87, p=0,033)$ і клапанів серця $(W R=3,85, p=0,009)$.

Рівень проліферації ендотелію судин прямо пов'язаний з виразністю лімфомакрофагальної інфільтрації строми міокарда ( $\mathrm{BF}=4,17$, $p=0,006 ; \tau=+0,297, p=0,002)$, периваскулярної ін- фільтрації (BF=3,23, $\mathrm{p}=0,030 ; \tau=+0,236, \mathrm{p}=0,013)$, клітинної інфільтрації клапанів серця ( $\mathrm{BF}=3,93$, $\mathrm{p}=0,026 ; \tau=+0,191, \mathrm{p}=0,044)$ та проліферації клапанного ендотелію (BF=10,12, $\mathrm{p}=0,003 ; \mathrm{\tau}=+0,367$, p<0,001). Окрім того, існують прямі кореляційні зв'язки Кендалла зі ступенями некрозу кардіоміоцитів ( $\tau=+0,263, p=0,005)$, набряку і склерозу строми міокарда (відповідно $\tau=+0,215, p=0,023$ i $\tau=+0,558, p<0,001)$, iї інфільтрації хмарними клітинами $(\tau=+0,545, p<0,001)$.

Зміни ендотелію судин серця визначаються морфологічними ушкодженнями імунокомпетентних органів - тимуса і селезінки. У першому з них бере участь зменшення клітин в мозковому шарі й тілець Гассаля, про що свідчать прямі кореляційні 
Огляди літератури, оригінальні дослідження, погляд на проблему

співвідношення Пірсона (відповідно $r=+0,208$, $\mathrm{p}=0,028$ і $r=+0,187, p=0,048)$, а в другому вірогідна значущість належить зменшенню лімфоїдної тканини, що демонструє дисперсійний аналіз БраунаФорсайта (BF=4,48, $\mathrm{p}=0,008)$.

Про роль порушень системи імунітету при формуванні патології серця у хворих на СЧВ свідчать прямі кореляційні зв'язки тяжкості вовчакової кардіопатії зі ступенем дисбалансу імуноцитів, з рівнями антиядерних антитіл, антитіл до кардіоліпіну і $\beta 2$-глікопротеїну-1, які взаємопов'язані з вмістом в крові гострофазових білків та молекул клітинної адгезії, з активністю матриксних металопротеїназ, з дисбалансом цитокінової мережі і системи комплементу $[15,16]$. Ці дані диктують необхідність проведення в майбутньому відповідних досліджень на запропонованій експериментальній моделі СЧВ у щурів.

Висновки. 1. Експериментальний СЧВ супроводжується розвитком кардіопатії в усіх тварин 3 гіпертрофією, дистрофією і некрозом кардіоміо- цитів, морфологічними ознаками склерозу коронарних судин, строми міокарда, ендокарда та клапанів серця.

2. Виразність проліферації судинного ендотелію має дисперсійні й прямі кореляційні взаємовідносини зі ступенем лімфомакрофагальної інфільтрації інтерстицію, периваскулярної і клапанної гістіоцитарної клітинної інфільтрації, з наявністю в стромі міокарда хмарних клітин, з некрозом ендокарда та колагенолізом клапанів.

3. Тяжкість змін тканин серця пов'язана зі зменшенням лімфоїдної тканини в селезінці, клітин в мозковому шарі та тілець Гассаля в тимусі, що відображає участь в патогенезі кардіальної патології у щурів з моделлю СЧВ імунних порушень.

Перспективи подальших досліджень. Подана модель буде корисною для вивчення патогенетичних побудов екстракардіальних ознак СЧВ, а також для розробки нових і вдосконалення відомих методів лікування захворювання.

\section{ЛІТЕРАТУРА}

1. Falasinnu T. Impact of sex on systemic lupus erythematosus-related causes of premature mortality in the United States / T. Falasinnu, Y. Chaichian, J. F. Simard // J. Womens Health. - 2017. - No. 26 (11). - P. 1214-1221.

2. Systemic autoimmunity induced by the TLR7/8 agonist Resiquimod causes myocarditis and dilated cardiomyopathy in a new mouse model of autoimmune heart disease / M. G. Hasham, N. Baxan, D. J. Stuckey [et al.] // Dis. Model Mech. 2017. - No. 10 (3). - P. 259-270.

3. Discordance of the Framingham cardiovascular risk score and the 2013 American College of Cardiology/American Heart Association risk score in systemic lupus erythematosus and rheumatoid arthritis / K. Jafri, A. Ogdie, A. Qasim [et al.] // Clin. Rheumatol. - 2017. - No. 9 (10). P. 203-209.

4. Systolic and diastolic heart function in SLE patients / M. Wislowska, D. Derez, M. Kochmazski, S. Sypuza // Rheumatol. Int. - 2009. - No. 29 (12). - P. 1469-1476.

5. E/E ratio is more sensitive than E/A ratio for detection of left ventricular diastolic dysfunction in systemic lupus erythematosus / S. W. Lee, M. C. Park, Y. B. Park, S. K. Lee // Lupus. - 2012. - No. 17 (3). - P. 195-201.

6. Ge X. Y. Assessment right atrial function in patients with systemic lupus erythematosus by speckle tracking and three-dimensional echocardiography / X. Y. Ge, L. Shao, Z. L. Zheng // Zhonghua Yi Xue Za Zhi. - 2016. No. 96 (47). - P. 3815-3818.

7. Cardiac tamponade in systemic lupus erythematosus / R. P. Goswami, G. Sircar, A. Ghosh, P. Ghosh // QJM. 2017. - No. 17 (10). - P. 172-178.

8. Yiu K. H. Editorial commentary for Dhakal: Heart failure in systemic lupus erythematosus: A problem to address / K. H. Yiu, H. F. Tse // Trends Cardiovasc. Med. 2017. - No. 8 (11). - P. 30165.
9. Cardiovascular magnetic resonance detects silent heart disease missed by echocardiography in systemic lupus erythematosus / S. Mavrogeni, L. Koutsogeorgopoulou, G. Markousis-Mavrogenis [et al.] // Lupus. - 2017. No. 1 (1).

10. Prevalence of resting-ECG abnormalities in systemic lupus erythematosus: a single-center experience / G. Myung, L. J. Forbess, M. L. Ishimori [et al.] // Clin. Rheumatol. - 2017. - No. 36 (6). - P. 1311-1316.

11. Lupus myocarditis: initial presentation and longterm outcomes in a multicentric series of 29 patients / G. Thomas, F. Cohen Aubart, L. Chiche [et al.] // J. Rheumatol. - 2017. - No. 44 (1). - P. 24-32.

12. Libman-Sacks endocarditis due to systemic lupus erythematosus activation after mitral valve plasty / T. Samura, K. Toda, D. Yoshioka [et al.] // Ann. Thorac. Surg. - 2017. - No. 104 (2). - P. 109-111.

13. Isolated tricuspid valve Libman-Sacks endocarditis in systemic lupus erythematosus with secondary antiphospholipid syndrome / D. Unic, M. Planinc, D. Baric [et al.] // Tex. Heart Inst. J. - 2017. - No. 44 (2). - P. 147-149.

14. The association between systemic lupus erythematosus and valvular heart disease: an extensive data analysis / A. Watad, S. Tiosano, N. Grysman [et al.] // Eur. J. Clin. Invest. - 2017. - No. 47 (5). - P. 366-371.

15. Azhar A. S. Cardiovascular complications in paediatric-onset systemic lupus erythematosus in Saudi Arabian patients / A. S. Azhar, O. M. Awlia, M. A. Muzaffer // Clin. Exp. Rheumatol. - 2017. - No. 35 (3). - P. 535-541.

16. Cardiac abnormalities in patients with systemic lupus erythematosus: the role of antiphospholipid antibodies / M. Monti, F. Borgognoni, L. Pastacci, G. M. Vincentelli // G. Ital. Cardiol. - 2016. - No. 17 (12). P. 1001-1007. 


\section{REFERENCES}

1. Falasinnu, T., Chaichian, Y., \& Simard, J.F. (2017). Impact of sex on systemic lupus erythematosus-related causes of premature mortality in the United States. J. Womens Health, 26 (11), 1214-1221. doi: 10.1089/jwh.2017.6334.

2. Hasham, M.G., Baxan, N., Stuckey, D.J., Branca, J., Perkins, B., Dent, O. et al. (2017). Systemic autoimmunity induced by the TLR7/8 agonist Resiquimod causes myocarditis and dilated cardiomyopathy in a new mouse model of autoimmune heart disease. Dis. Model Mech., 10 (3), 259270. doi: $10.1242 / \mathrm{dmm} .027409$.

3. Jafri, K., Ogdie, A., Qasim, A., Patterson, S.L., Gianfrancesco, M., Izadi, Z. et al. (2017). Discordance of the Framingham cardiovascular risk score and the 2013 American College of Cardiology/American Heart Association risk score in systemic lupus erythematosus and rheumatoid arthritis. Clin. Rheumatol., 9 (10), 203-209. doi: 10.1007/ s10067-017-3860-x.

4. Wislowska, M., Derez, D., Kochmazski, M., \& Sypuza, S. (2009). Systolic and diastolic heart function in SLE patients. Rheumatol. Int., 29 (12), 1469-1476.

5. Lee, S.W., Park, M.C., Park, Y.B., \& Lee, S.K. (2012). $E / E$ ratio is more sensitive than $E / A$ ratio for detection of left ventricular diastolic dysfunction in systemic lupus erythematosus. Lupus, 17 (3), 195-201.

6. Ge, X.Y., Shao, L., \& Zheng, Z.L. (2016). Assessment right atrial function in patients with systemic lupus erythematosus by speckle tracking and three-dimensional echocardiography. Zhonghua Yi Xue Za Zhi, 96 (47), 3815-3818. doi: 10.3760/cma.j.issn.0376-2491.2016.47.010.

7. Goswami, R.P., Sircar, G., Ghosh, A., \& Ghosh, P. (2017). Cardiac tamponade in systemic lupus erythematosus. QJM, 17 (10), 172-178. doi: 10.1093/qjmed/hcx195.

8. Yiu, K.H., \& Tse, H.F. Editorial commentary for Dhakal: Heart failure in systemic lupus erythematosus: A problem to address. Trends Cardiovasc. Med., 8 (11), 30165. doi: 10.1016/j.tcm.2017.11.001.

9. Mavrogeni, S., Koutsogeorgopoulou, L., MarkousisMavrogenis, G., Bounas, A., Tektonidou, M., Lliossis, S.C. et al. (2017). Cardiovascular magnetic resonance detects silent heart disease missed by echocardiography in systemic lupus erythematosus. Lupus, 1 (1), doi: 10.1177/ 0961203317731533.

10. Myung, G., Forbess, L.J., Ishimori, M.L., Chugh, S., Wallace, D., Weisman, M.H. (2017). Prevalence of resting-ECG abnormalities in systemic lupus erythematosus: a singlecenter experience. Clin. Rheumatol., 36 (6), 1311-1316. doi: 10.1007/s10067-017-3582-0.

11. Thomas, G., Cohen, A.F., Chiche, L., Haroche, J., Hié, M., Hervier, B. et al. (2017). Lupus myocarditis: initial presentation and longterm outcomes in a multicentric series of 29 patients. J. Rheumatol., 44 (1), 24-32. doi: 10.3899/ jrheum.160493.

12. Samura, T., Toda, K., Yoshioka, D., Nakamura, T., Miyagawa, S., Yoshikawa, Y. et al. (2017). Libman-Sacks endocarditis due to systemic lupus erythematosus activation after mitral valve plasty. Ann. Thorac. Surg., 104 (2), 109-111. doi: 10.1016/j.athoracsur.2017.01.073.

13. Unic, D., Planinc, M., Baric, D., Rudez, I., Blazekovic, R., Senjug, P. et al. (2017). Isolated tricuspid valve Libman-Sacks endocarditis in systemic lupus erythematosus with secondary antiphospholipid syndrome. Tex. Heart Inst. J., 44 (2), 147-149. doi: 10.14503/THIJ-16-5856.

14. Watad, A., Tiosano, S., Grysman, N., Comaneshter, D., Cohen, A.D., Shoenfeld, Y. et al. (2017). The association between systemic lupus erythematosus and valvular heart disease: an extensive data analysis. Eur. J. Clin. Invest., 47 (5), 366-371. doi: 10.1111/eci.12744.

15. Azhar, A.S., Awlia, O.M., \& Muzaffer, M.A. (2017). Cardiovascular complications in paediatric-onset systemic lupus erythematosus in Saudi Arabian patients. Clin. Exp. Rheumatol., 35 (3), 535-341.

16. Monti, M., Borgognoni, F., Pastacci, L., \& Vincentelli, G.M. (2016). Cardiac abnormalities in patients with systemic lupus erythematosus: the role of antiphospholipid antibodies. G. Ital. Cardiol., 17 (12), 1001-1007. doi: $10.1714 / 2612.26892$.

\title{
МОРФОЛОГИЧЕСКИЕ ИЗМЕНЕНИЯ СЕРДЦА У ЖИВОТНЫХ С ЭКСПЕРИМЕНТАЛЬНОЙ СИСТЕМНОЙ КРАСНОЙ ВОЛЧАНКОЙ
}

\author{
๑О. В. Синяченко ${ }^{1}$ А. В. Бреславець², Е. Д. Егудина \\ Донецкий национальный медицинский университет ${ }^{1}$, г. Лиман \\ Научно-практический центр клинической и профилактической медицины', г. Киев \\ Днепропетровская государственная медицинская академияз, г. Днепр
}

РЕЗЮМЕ. Патология сердца при системной красной волчанке (СКВ) относится к наиболее частым проявлениям заболевания и во многом определяет его прогноз, а морфологические изменения поражений миокарда, эндокарда и коронарных сосудов остаются изученными недостаточно. Гистологическая оценка отдельных кардиальных структур проводится на естественных моделях СКВ на линейных мышах.

Цель - изучить в эксперименте на животных (крысах) с моделью СКВ степень повреждения миокарда, эндокарда и сосудов сердца, сопоставив полученные результаты с данными гистологического исследования тканей тимуса и селезенки.

Материал и методы. Моделирование СКВ выполнено на 53 белых беспородных крысах (34 самки и 19 самцов) с использованием введения полного адъюванта Фрейнда, селезеночной дезоксирибонуклеиновой кислоты 
Огляди літератури, оригінальні дослідження, погляд на проблему

крупного рогатого скота, циклофосфамида, азида и дезоксирибонуклеината натрия, вскармливанием животных с добавлением в пищу сульфата кадмия, оксибутирата лития и молибдата аммония. Гистологические препараты сердца окрашивали гематоксилином и эозином, альциановым синим (pH=2,6), по ван Гизон, ставили PAS-реакцию.

Результаты. Экспериментальный СКВ сопровождается развитием кардиопатии у всех животных с гипертрофией, дистрофией и некрозом кардиомиоцитов, морфологическими признаками склероза коронарных сосудов, стромы миокарда, эндокарда и клапанов сердца, пролиферацией сосудистого эндотелия, которая имеет дисперсионные и прямые корреляционные связи со степенью лимфомакрофагальной инфильтрации интерстиция, периваскулярной и клапанной гистиоцитарной клеточной инфильтрацией, а характер повреждений эндотелия сосудов тесно связан с наличием в строме миокарда облачных клеток, определяется некрозом эндокарда и колагенолизом клапанов, уменьшением лимфоидной ткани в селезенке, а также клеток в мозговом слое и телец Гассаля в тимусе.

Выводы. При экспериментальной волчаночной кардиопатии наблюдается закономерное поражение всех структур сердца, причем в их патогенетических построениях принимают участие иммунные нарушения, на что указывают повреждения соответствующих структур иммунокомпетентных органов - тимуса и селезенки.

КЛЮчЕВЫЕ СЛОВА: системная красная волчанка; модель; крысы; сердце; морфология.

\title{
MORPHOLOGICAL HEART CHANGES IN ANIMALS WITH EXPERIMENTAL SYSTEMIC LUPUS ERYTHEMATOSUS
}

\author{
๑O. V. Syniachenko', A. V. Breslavets ${ }^{2}$, Ye. D. Yehudina ${ }^{3}$ \\ Donetsk National Medical University', Lyman \\ Scientific Practical Center of Preventive and Clinical Medicine², Kyiv \\ Dnipropetrovsk Medical Academy33, Dnipro
}

SUMMARY. Heart pathology in systemic lupus erythematosus (SLE) refers to the most common manifestations of the disease and largely determines its prognosis. The pathogenetic constructions of myocardium, endocardium and coronary vessel lesions remain insufficiently studied. Histological evaluation of separate cardiac structures is performed on native models of SLE in linear mice.

The aim of the study - to learn in the experiment on animals (rats) with SLE model the degree of cardiomyocytes, myocardium, endocardium, valves and cardiac vessel damage, comparing the results with thymus and spleen tissues histological data.

Material and Methods. The SLE modelling was performed in 53 white non-breeding rats (34 females and 19 males) using full Freund's adjuvant, splenic deoxyribonucleic acid of cattle, cyclophosphamide, azid and sodium deoxyribonucleate. Cadmium sulfate, lithium oxybutyrate and ammonium molybdate were added for feeding animals. Histological heart specimen were stained with hematoxylin and eosin, altsyon blue $(\mathrm{pH}=2.6)$, van Gieson. PAS-reaction was applied.

Results. Experimental SLE is accompanied by the development of cardiopathy in all animals with cardiomyocytes hypertrophy, dystrophy and necrosis, morphological signs of coronary vessel, myocardial stroma, endocardium and heart valves sclerosis, proliferation of vascular endothelium, which has dispersion and direct correlation relationships with the degree of lymphoma-macrophage infiltration, interstitial tissue, perivascular and valvular histiocytic cell infiltration, and the vessels endothelium damage nature is closely linked to the presence of mast cells in myocardial stroma, it is defined by endocardium necrosis and valves collagenolysis, decrease in spleen lymphoid tissue, and also in the brain layer cells and Gassal cells in the thymus. We selected those signs of experimental lupus cardiopathy, which simultaneously had Brown-Forsythe dispersion and Kendall non-parametric correlation relations. It turned out that the hypertrophy of cardiomyocytes is directly influenced by the severity of perivascular cell infiltration and the proliferation of vascular endothelium and valves, but necrotization of cardiomyocytes - by the degree of perivascular sclerosis. As the WilcoxonRao multivariate analysis showed, vascular endothelial changes affect the integral manifestations of myocardium, endocardium and heart valve damages. The presented model will be useful for studying the pathogenetic constructions of extracardiac signs of SLE, as well as for developing new and improving the known methods of the disease treatment.

Conclusions. In the case of experimental lupus cardiopathy, there is a heart structures lesion, what is more, the immune disorders are involved in their pathogenetic constructions, as indicated by the damage of the immunocompetent organs' (thymus and spleen) corresponding structures.

KEY WORDS: systemic lupus erythematosus; model; rats; heart; morphology. 